\title{
ALIGNMENT MODEL FOR TRUNK ROAD NETWORK MAINTENANCE OUTSOURCING
}

\author{
Ena E. ORUGBO, Babakalli M. ALKALI, Anjali DESILVA, David K. HARRISON \\ School of Engineering and Built Environment, Glasgow Caledonian University, Cowcaddens Road, \\ G4 OBA Glasgow, UK
}

Received 01 Mar 2013; accepted 03 Jun 2013

\begin{abstract}
Road maintenance outsourcing is now the foremost strategy by which road authorities procure maintenance works. Despite growing application of road maintenance outsourcing, there are conflicting estimates on the effectiveness of road maintenance outsourcing and shortage of appropriate models to align over optimistic expectations of road authorities from road maintenance outsourcing with substantiated benefits. This paper investigates the efficacy of road maintenance outsourcing. In this paper, the different variants of road maintenance outsourcing and road maintenance works are evaluated with a SWOT analysis and a comprehensive literature review respectively. In addition, a road maintenance outsourcing alignment model based on a decision tree and Balance Score Card is proposed and illustrated with a Nigerian trunk road network authority as a case study. The result of the SWOT analysis and comprehensive literature review establishes fresh insight into road maintenance outsourcing dynamics. The presented road maintenance outsourcing alignment model provides adequate pathways that could assist road authorities identify the most appropriate road maintenance outsourcing variant for road maintenance procurement. In addition it aligns actual benefits and expectations of road maintenance outsourcing and facilitates development of SMART metrics for effective assessment of road maintenance outsourcing. The proposed model is applicable across other infrastructures.
\end{abstract}

Keywords: trunk road networks, maintenance outsourcing, SWOT, decision tree, balance score card.

\section{Introduction}

The traditional way of procuring road maintenance based on insourcing has failed to match the goals of cutting maintenance expenses and enhancing services on road networks (Stenbeck 2004; Porter 2006). This has spurred a paradigm shift on how road maintenance is being procured (Porter 2001). Instead, road maintenance outsourcing has in the last decades become the foremost strategy for procuring road maintenance (Zietlow 2011). Road maintenance outsourcing is the partial or total transfer of the management of road networks to the private sector with a view to inspire innovation, cut cost and improve efficiency (Tomanelli 2003). However, there are conflicting estimations on the efficacy of road maintenance outsourcing and not all road agencies have had positive experiences when deciding to outsource road maintenance (Dlesk, Bell 2006). Washington State Department of Transport (2004) review of Highway Maintenance Outsourcing states that "initial claims of projected cost savings and service benefits are, at best, difficult of substantiation and, at worst, overstated". In addition, objectives for adopting road maintenance outsourcing differs across road authorities, various classes of road maintenance works and competing variants of road maintenance outsourcing exists, and shortage of appropriate models to manage road authorities over optimistic expectations from road maintenance outsourcing increase the degree of complexity, multidimensionality and robustness of the issue. There is a need for fresh insight into the road maintenance outsourcing process.

This paper therefore presents an evaluation of the efficacy of road maintenance outsourcing using a comprehensive literature review and Strength, Weakness, Opportunity and Threat (SWOT) analysis respectively. In this paper, a trunk road network maintenance outsourcing alignment model that could assist road authorities select the most appropriate road maintenance outsourcing variant to procure road maintenance is also proposed. The alignment model is a new development, and is developed using a decision tree and Balance Score Card (BSC) and illustrated using a Nigerian trunk road network authority as a case study. The comprehensive literature review appraises the various classes of road maintenance works, divulges the diversity in the way road maintenance is procured and the several standpoints taken on the issue and provides a solid underpinning for the SWOT analysis.

The SWOT analysis methodologically captures the capabilities and limitations of existing road maintenance

Corresponding author: Ena E. Orugbo

E-mail: ena.orugbo@yahoo.ca 
outsourcing variants. FHWA (2004a) used a SWOT analysis to capture and analyse the complexities of mega highway projects. For the proposed alignment model, the decision tree provides adequate pathways for the road maintenance outsourcing variant selection process. Zhou (2011) study on Co-Location Decision Tree for Enhancing Decision-Making of Pavement Maintenance and Rehabilitation states that analysing the outcomes of a few alternative actions using decision trees before making a decision produces the most favourable or least painful consequences. Decision trees have been used extensively to improve highway maintenance selection decisions (Jahren et al. 1999; Wei, Tighe 2003) but their extension to road maintenance outsourcing decisions is limited.

Hicks et al. (2000) developed a simplified maintenance and rehabilitation decision tree for asphalt pavements for selecting the most appropriate maintenance strategy for particular pavements and says there is no much difference between decision matrices and decision trees as they both depend on a cluster of attributes to reach suitable maintenance or renewal decisions but decision trees afford a more methodical and structured approach to selection processes. The Balance Score Card module of the alignment model is used to analyse objectives of road maintenance outsourcing against expectations and develop SMART metrics to measure and align road maintenance outsourcing performance against identified core objectives. Balance Score card is an established performance management tool (Kaplan, Norton 2005) and has found application in highway maintenance to give tangibility to intangible performance metrics such as service quality, convert strategy into action and provide strategic feedback and learning (World Bank 2008; New Hampshire DOT 2011).

The case study road authority used in this study administers Nigeria's $34,120 \mathrm{~km}$ long trunk road network (Chidoka 2011). Nigeria is used in this study because road maintenance outsourcing is quite new there and Nigeria has witnessed failed implementation of road maintenance outsourcing with dire effects (Ondo State Government 2012). However where road maintenance outsourcing is not new, there are now approximately half way through their duration (Noble 2004) and availability of consistent and robust guidelines to appraise the efficiency and effectiveness of road maintenance outsourcing is limited (Piñero et al. 2003). Lastly, this study focuses on trunk road networks because there are strategic infrastructures whose maintenance has great impact on quality of life and economic vitality of nations (FHWA 2004b; The UK Roads Liaison Group 2005; Halcrow 2011).

\section{Why effective trunk road network maintenance?}

Trunk road networks or highways (HM Treasury 2012) are the largest public owned assets (Wallace 2012) covering several miles thus effective maintenance is not attainable with mere implementation of road maintenance outsourcing instead the most appropriate road maintenance outsourcing variant. Furthermore, trunk road networks road users' dissatisfaction and maintenance backlogs have increased due to faster deterioration and depreciation rates and inadequate maintenance of trunk road networks (Orugbo et al. 2012). For example, Audit Scotland (2011) reports a Scottish trunk road network maintenance backlog of $£ 700$ million and Schliessler, Bull (2004) study shows that in Latin American and Caribbean countries region road asset value depreciates by $£ 1.99$ billion annually due to inadequate maintenance.

In addition, with increased universal environmental awareness and depleting natural resources, road maintenance objectives activities now have to be considered more carefully with sustainability in view. Prior to this era key road network maintenance objective was adequate maintenance. However, Ozbek et al. (2010) states that currently, the key road maintenance objective is cost effective maintenance, to achieve maximum performance and safety from existing road systems while investing minimum amount of money. To achieve effective trunk road maintenance high reliability road maintenance authorities have procured maintenance by outsourcing but also further delineated trunk road maintenance works into project and program level maintenance works.

\subsection{Project level maintenance}

The North Wales Trunk Road Agency (2013) defines project level trunk road network maintenance as capital or renewal trunk road network maintenance works designed to enhance the value of trunk road networks and improve some sections over a sustained period of time. Project level trunk road network maintenance works usually entail procurement, construction and installation of new elements of the network to replace decrepit or upgrade existing networks. For example, The European Development Fund (COFED) spent an estimated \$164 million to renew the Democratic Republic of Congo's road network (Infrastructure Consortium for Africa 2010). Project level trunk road network maintenance works are well thought out and scheduled to ensure minimal network disruption as shown in Table 1 below.

Table 1. Works analysis for project and program level trunk road network maintenance works

\begin{tabular}{|c|c|c|}
\hline & Project & Program \\
\hline Aim & Network improvement & $\begin{array}{l}\text { Operational } \\
\text { availability }\end{array}$ \\
\hline Cost & $£ 250,000$ upward & $£ 250,000$ downward \\
\hline Frequency & Low & High \\
\hline Approach & Preventive & Reactive \\
\hline
\end{tabular}

Source: DFT 2009 and further expounded by authors. 


\subsection{Program level maintenance}

However, program level trunk road network maintenance works which cater for repair of categoryl defects and winter maintenance have a higher frequency and are mostly reactive maintenance measures to keep the road network safe and operational as shown in Table 1 above (PAGplus 2010). Category1 defects such as potholes are failures that require prompt attention as they represent an imminent hazard or risk of accelerating deterioration of trunk road networks. Category 1 defects related failures maintenance works make a good proportion of program level trunk road network maintenance works and account for disruption of journeys (PAGplus 2009). The yearly cost of program level trunk road network maintenance works are a lesser quota of trunk road network investment cost, typically about $3 \%$ to $4 \%$, however the economic rationality for program level trunk road network maintenance works is incontrovertible. ILO (2012) study on understanding road maintenance reiterates and states that the huge project level maintenance investments such as modernization and implementation of leading strategies such as outsourcing are of limited importance if there is no effective program level maintenance system.

\section{Road maintenance outsourcing variants}

Several road maintenance outsourcing variants exists and are as follows: Traditional Road Maintenance Contracts (TRMC), Build Operate and Transfer (BOT), Performance Based Road Contracts and Operations (PBRC) and Operations and Maintenance (O\&M) contracts. These road maintenance outsourcing variants are best suited in different context. For example project level trunk road maintenance works have mostly taken the Build Operate and Transfer variant while program level works have taken the Performance Based Road Contracts variant (Transport Research Board 2009). Therefore, evaluating the efficacy of road maintenance outsourcing using only one variant and not considering the complexities cited in the introductory section of this paper above is untenable.

This is at the crux of the disparity of opinions on the efficacy of road maintenance outsourcing. For example, proponents of road maintenance outsourcing state a desire to deliver cost and efficiency savings as the key reason road authorities procure maintenance with outsourcing (Central Bank of Nigeria 2003). Disputants cite the yearning to transfer risk to contractors and attract private sector financing (Zietlow 2004; Stenbeck 2007). However, Palmer (2000) report on contract issues and financing in public-private partnerships says that the Build Operate and Transfer variant has delivered anticipated benefits. The same cannot be said of the other road maintenance outsourcing variants. For example, Gahm (2008) says performance based road maintenance contracts have not delivered expected service levels on trunk road networks while (Österberg 2003) cites a dearth of innovation and narrow focus on cost savings instead of a balanced focus across cost and efficiency as draw backs of other variants.

\subsection{Traditional road maintenance contracts}

TRMC entails contracts where a service provider is paid a stated sum by a road authority to execute a defined task without transferal of risk to service provider (Federal Roads Maintenance Agency 2007). Contractors are asked to submit bids against a Bill of Quantities (BOQ) for specific road maintenance works and the lowest bidder (Nigeria)/most economically advantageous tender (UK) contractor is typically selected to execute the task in line with site specific guidelines issued by the road authority. This is the most utilized road maintenance outsourcing variant, Nigeria inclusive (Federal Roads Maintenance Agency 2009). Osime et al. (2006) study on Road traffic accident trends in Nigeria however shows an increase in road accident fatality by $10 \%$ from 1998 to 2003 . This increase in fatality rates and reduced service levels on road networks in Nigeria depicts that this variant in isolation cannot meet ever changing needs of road users.

\subsection{Build operate and transfer}

Kumaraswamy and Zhang (2001) study shows that Thailand, Turkey, France and Hong Kong are among nations that have successfully used the BOT variant to procure maintenance. In BOT schemes a private firm finances, designs, builds, operates and maintains a trunk road network on behalf of a road authority for a period of 1 to 3 decades. For example, the $£ 6.2$ billion Design, Build, and Finance and Operate (DBFO) reconstruction contract of the, M25 in the UK for a period of 30 years; in the UK BOT contracts are called DBFO contracts (Highway Agency 2009). The attention of maintenance in the elementary stages of BOT schemes leads to increased maintenance efficiency and reduced life cycle costs (ADB 2006). Shaoul et al. (2007), study on "Highway robbery? A financial analysis of Design, Build, and Finance and Operate in UK roads" shows that DBFO's have now become the established option for project level trunk road network management services in the UK. Despite the success attributed to BOT's, Karim (2011) states that BOT may lead to knowledge gaps if contractors prosecute road developments alone. In Scotland, the road authority plays an oversight role via the appointment of an Engineer for each DBFO project but in no way interferes with the daily management of projects but the contractor is demanded to return the trunk road networks with a pre-determined minimum useful life. However there are notable failed implementations of the Build Operate and Transfer variant. For example, the Nigerian Government outsourced the management of the 105-kilometre LagosIbadan highway via a 25-year concession worth $£ 370$ million (Road Traffic Technology 2012). However, 3 years after the contract was signed work was yet to commence. The Nigerian Government citing financial debility of the contractor cancelled the contract and then reverted to the TRMC variant to procure maintenance of the highway but within that 3 years gap the highway became a nightmare for road users (Ondo State Government 2012). 


\subsection{Performance-based road contracts}

Transport Research Board (2009) study on PerformanceBased Contracting for Maintenance, A Synthesis of Highway Practice shows that developed and developing nations across continents have employed performance based road contracts to maintain their strategic road networks. Performance based road maintenance contracts is a sort of contract between a road authority and a private firm in which explicit objectives and key performance indicators on predetermined service levels are set for the construction and maintenance, or exclusive maintenance of road networks (Stankevich et al. 2005). Performance based road maintenance contracts usually run for 3 to 5 years with penalties or incentives for contractors based on performance. However, there are concerns that metrics used for monitoring performance based road maintenance contracts were adopted from conventional road maintenance methods hence ineffective. Piñero (2003) therefore developed a framework for monitoring performance based road maintenance contracts and states that without appropriate monitoring; performance based road maintenance contracts would have adverse outcomes. In Scotland, the monitoring of performance based contracts is contracted to the Performance Audit Group (PAGplus 2009; Transport Scotland 2010). Lancelot (2010) study on the Brazilian experience of performance based road contracts tagged performance based road maintenance contracts initiative a success.

The USA and Australian experience is similar, Carpenter et al. (2003) reports cost savings of about $15 \%$ lower than traditional contract forms. Disputants are however quick to question the opportunity cost of these reported cost savings. Stenbeck (2007) study on promoting innovation in transportation infrastructure maintenance reports that in countries such as Canada performance based road maintenance contracts have ended up been $10 \%$ and $50 \%$ more expensive than traditional maintenance contracts. More importantly, Baltzer (2007) study on long term performance based road maintenance contracts in Denmark depicts no improved quality and service due to performance based road maintenance contracts. Zietlow (2011) reports that, performance based road maintenance contracts have succeeded in transferring risk to contractors. Karim (2010) study on evaluation of attempts for effective road maintenance states that anticipated technological benefits from performance based road maintenance contracts remains elusive due to contractor's hording knowledge for competitive reasons.

Ozbek (2004) study on development of performance warranties for performance based road maintenance contracts says that except warranty clauses are imbedded within performance based road maintenance contracts to motivate contractors to implement superior maintenance practices to improve the overall condition of the asset during the contract period performance based road maintenance contracts really cannot improve short or long term performance of road networks. British Colombia (2012)
Ministry of transportation and infrastructure, highway maintenance agreements for performance based road maintenance contracts are highly flexibility. Flexible clauses such as annual price adjustment to take into account changes in price indices for labor and fuel exist.

\subsection{Operations and maintenance contracts}

Operations and Maintenance contracts is a variant of road maintenance outsourcing which covers works ranging from technical assistance through to full-blown operation and maintenance agreements and so it is difficult to generalize about them (DFID 1998). The main common features are that the awarding authority engages the contractor to manage a range of activities for a relatively short time period of 0 to 5 years (World Bank 2011). $\mathrm{O} \& \mathrm{M}$ contracts are task specific and input rather than output focused though some may have flexible performance requirements. The Secretariat for the Committee on Infrastructure (2009) policy initiatives however states that the prospects of successfully using the $\mathrm{O} \& \mathrm{M}$ variant to achieve outsourcing objectives depends on a precise policy and regulatory framework being spelt out due to the complexities of road maintenance outsourcing.

\section{Discussion}

The evaluation of existing road maintenance outsourcing variants above shows that the interest on implementing road maintenance outsourcing is still growing. However, there is unanimity that evaluating the benefits accrued as an outcome of applying road maintenance outsourcing for procuring road maintenance is complex and difficult. The results of the SWOT analysis on existing road maintenance outsourcing variants as shown in Table 2 below however reduces this complexity by capturing and analyzing the individual capabilities and limitations of

Table 2. SWOT analysis of road maintenance outsourcing variants

\begin{tabular}{cllll}
\hline Variant & Strength & Weakness & Opportunity & Threat \\
\hline O\&M & $\begin{array}{l}\text { Reduces } \\
\text { agency's } \\
\text { workload }\end{array}$ & $\begin{array}{l}\text { Limited } \\
\text { potential for } \\
\text { upgrade }\end{array}$ & $\begin{array}{l}\text { Budgets } \\
\text { known for } \\
\text { long period }\end{array}$ & $\begin{array}{l}\text { Difficult to } \\
\text { monitor } \\
\text { \& scope }\end{array}$ \\
BOT & $\begin{array}{l}\text { Established } \\
\text { and attracts } \\
\text { investment }\end{array}$ & $\begin{array}{l}\text { Complex } \\
\text { with some }\end{array}$ & $\begin{array}{l}\text { Improves } \\
\text { network and } \\
\text { efficiency }\end{array}$ & $\begin{array}{l}\text { Mediation } \\
\text { process } \\
\text { lengthy }\end{array}$ \\
PBRC & $\begin{array}{l}\text { Goals \& } \\
\text { service } \\
\text { level clear }\end{array}$ & $\begin{array}{l}\text { Hidden } \\
\text { opportunity } \\
\text { cost }\end{array}$ & $\begin{array}{l}\text { Spurs } \\
\text { change and } \\
\text { cuts cost }\end{array}$ & $\begin{array}{l}\text { Could lead } \\
\text { to skill } \\
\text { gaps }\end{array}$ \\
TRMC & $\begin{array}{l}\text { Highly } \\
\text { flexible }\end{array}$ & $\begin{array}{l}\text { Unsuitable } \\
\text { for mega } \\
\text { projects }\end{array}$ & $\begin{array}{l}\text { Reduces } \\
\text { response } \\
\text { times }\end{array}$ & $\begin{array}{l}\text { Not } \\
\text { customer } \\
\text { centric }\end{array}$ \\
\hline
\end{tabular}

Source: DFID (1998); ADB (2006); Zietlow (2006); Silva, Liautaud (2011); Transport Research Board (2009); World Bank (2011). 
existing road maintenance outsourcing variants which is a more robust, multidimensional and an emergent approach towards appraising the efficacy of road maintenance outsourcing as a viable road maintenance strategy.

The SWOT results show that the $\mathrm{O} \& \mathrm{M}$ variant gives road authorities more stability to plan and strategize on better service delivery mechanisms that carters for long term network needs but has a weakness of limited potential for network improvement. The $\mathrm{O} \& \mathrm{M}$ variant has a threat of difficulties in specifying some types of works. For the BOT variant, it is politically centric due to the mega size of project level trunk road network maintenance works that BOT is synonymous with and whenever there is a change of central Government with a new policy agenda, BOT projects can run in to hurdles. However it is well established and is a channel for the needed private sector financing. As regards the PBRC variant, it is widely accepted for its performance metrics and cost reduction but can easily become a weakness when performance metrics are convectional. Karim (2011) used the Swedish Road Administration's Review of Maintenance Activities program as an example, where a reduced roadside mowing width along the road sides from $7 \mathrm{~m}$ to $3 \mathrm{~m}$ and a reduced cleaning rate for road reflectors reduced cost but also cut road safety and visibility. The TRMC variant has the status of a fail-safe mechanism due to its flexibility when other variants fail in their implementation stages as was the case of the Nigerian BOT cited in Section 2.2 above. The TRMC variant also clearly delineates risk and control in the preview of the road authorities and it is easy to monitor.

An established understanding of various classes of road maintenance works and existing road maintenance outsourcing variants (capabilities and limitations inclusive) is fundamental towards selecting the most appropriate road maintenance outsourcing variant to procure trunk road network maintenance. A clear definition of the core objectives and expectations for procuring road maintenance with outsourcing is the next step. Central Bank of Nigeria (2003) and Segal et al. (2003) studies state objectives and expectations for outsourcing road maintenance as follows: cost savings, improve efficiency, improve quality, spur innovation', access expertise, meet peak demands and speed project delivery, increase flexibility, better manage risks and attract finance. These objectives are skewed towards varying stakeholder's core objectives. For example, The Secretariat for the Committee on Infrastructure (2006) report on financing of the National Highway Development Programme shows that the Indian Central Government required a mammoth investment of $£ 33$ billion to sustain her highways and decided to procure highway maintenance through outsourcing to achieve this objective.

In addition, Scottish trunk road network carters for $60 \%$ of freight traffic (Halcrow 2011) which shows that Heavy Goods Vehicle road users are more disposed towards service levels improvement on road networks to

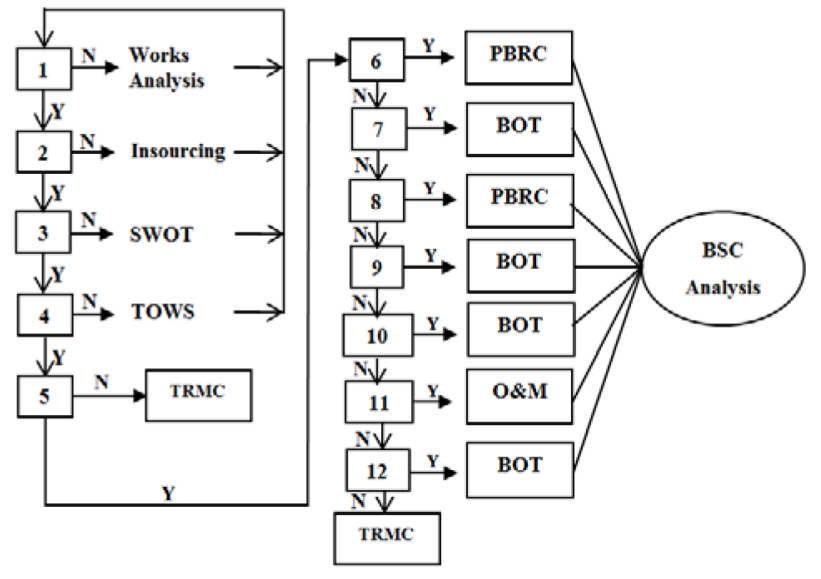

Fig. 1. Road Maintenance outsourcing Alignment Model

enable their goods and services competitive favorably internationally. Zietlow (2004) study presented a risk distribution model for road maintenance outsourcing against insourcing and shows that road authorities are more disposed towards risk reduction due to rising cost of claims and increased vehicle operating cost which Segal et al. (2003) estimates at $£ 27.5$ billion/year in the US. These dynamic, competing and conflicting core objectives of road maintenance stakeholder's make road maintenance outsourcing decisions increasingly difficult (Bucyk, Lali 2005). The proposed trunk road network maintenance alignment model as shown in Figure 1 below however structures and manages these complexities.

For this illustration of the road maintenance alignment model 13 leading yes or no questions were developed as shown below in Appendix 1 to direct the path of the decision tree. The two possible outcomes approach was adopted for simplicity, to minimize bias, balance both known and unknown factors that can influence the path of the decision tree and enable further exploration of outcomes. For example, No to question 4 as shown in Figure 1 above leads to a threats and opportunities weaknesses and strengths (TOWS) analysis. The TOWS analysis is imbedded within the road maintenance outsourcing alignment model to enable road authorities overcome and examine ways their organizations can take advantage of opportunities and minimize threats by exploiting strengths and overcoming weaknesses of the existing road maintenance outsourcing variants. The core objectives road authorities procure road maintenance through outsourcing was abridged from 9 to 7 in consensus with road maintenance experts from the case study road authority as shown in questions 6 to 12 of Appendix 1 because some of the objectives were interrelated and only objectives which are Specific, Measurable, Attainable, Realistic and Time-sensitive (SMART) are captured in the model.

Thereafter semi-structured interviews were conducted with the road maintenance experts from the case study road authority to proffer answers to the decision tree questions and develop metrics for the Balance score 
card analysis in a decision workshop mode. Various interview sessions were conducted and whenever the consensus answer of the road maintenance experts terminated in a node before the option of a road maintenance outsourcing variant, the outcome is executed and the process restarted. This is a unique feature of the alignment model, as it not only directs the selection process but also facilitates learning, feedback and interaction between maintenance personnel. After the decision process was repeated twice it finally terminated at Question 9 which corresponds to the BOT variant as the most appropriate variant with which they can procure their road network maintenance. The model's result was buttressed by the road maintenance experts citing years of neglect and inadequate investment which left the network in a deplorable condition needing huge capital investments. Whatever choice of road maintenance outsourcing variant was the final outcome, the BSC analysis is still proposed due to the non-alignment of their existing metrics against objectives. In addition, road maintenance variables such as traffic volumes, failure rates and customer expectations are dynamic thus the BSC analysis enables the development of adaptable metrics that match up comings. The BSC metrics captured in Appendix 2 was elicited in the decision workshop from the road maintenance experts. An alignment percentage can then be calculated subsequently by finding the percentage difference between measures in Appendix 2 against experienced measures within a time scale suitable to the road authority. The presented road network maintenance alignment model is simplistic, informative, handles both program and project level road maintenance works and flexible (adoptable to any road authority and infrastructure). For example, road authorities can select road maintenance outsourcing objectives and develop metrics suitable to their context. Further investigation of the model is still on-going using a cause and effect analysis of objectives as well as auto correlation analysis to justify the linear relationships of the objectives and results will be presented in future publications.

\section{Conclusions}

In this paper, a Road maintenance outsourcing alignment model which aids road authorities select the most appropriate road maintenance outsourcing variant to effectively procure trunk road network maintenance has been presented. To illustrate the model a Nigerian road authority was used as a case study. A decision tree and BSC is used to develop the alignment model. The former structures and directs the model path while the later analyses road maintenance outsourcing objectives, aids development of SMART metrics to measure performance and aligns anticipated measures against experienced measures enabling cropping of over optimistic expectations from road maintenance outsourcing.

The results of the SWOT analysis and extensive literature review increases visibility into trunk road network maintenance outsourcing dynamics, provides anticipated information on capabilities and limitations of existing road maintenance outsourcing variants, appraises the various classes of road maintenance works and provides a solid underpinning for future contextual studies into road maintenance outsourcing. This paper shows that road maintenance outsourcing is effective for trunk road network maintenance but an established understanding of road maintenance outsourcing dynamics is vital to reaching more informed road maintenance outsourcing decisions thus better service levels on road networks. Lastly alignment of anticipated measures against experienced measures of road maintenance outsourcing is crucial for road authorities' to rightly assess the efficacy of road maintenance outsourcing in their specific context.

\section{References}

ADB. 2006. Public-private partnership handbook. Manila, Philippines: Asian Development Bank (ADB). 100 p.

Audit Scotland. 2011. Maintaining Scotland's roads: a follow up report prepared for the Auditor General for Scotland and the Accounts Commission. Edinburgh: Audit Scotland. 17 p.

Baltzer, S. 2007. Long term performance-based maintenance contracts in Denmark, Nordic (3): 10-11.

British Colombia. 2004. Best management practices for highway maintenance activities. Victoria, BC: British Colombia Ministry of Transportation.

Bucyk, N.; Lali, N. 2005. The evolution of highway maintenance outsourcing in Alberta, in Proc. of the Annual Conference of the Transportation Association of Canada (TAC-2005), 18-21 September 2005, Calgary, Alberta, $14-25$.

Carpenter, B.; Fekpe, E.; Gopalakrishna, D. 2003. Performance based contracting for the highway construction industry: an evaluation of the use of innovative contracting and performance specification in highway construction. Battelle report. Virginia. NCPPP. 49 p.

Central Bank of Nigeria. 2003. Highway maintenance in Nigeria: lessons from other countries, Research Department Occasion Paper No. 27. Abuja: Central Bank of Nigeria. $65 \mathrm{p}$.

Chidoka, O. 2011. Successes and challenges of a lead agency and the multisectoral nature of road safety. Federal Road Safety Corps, Abuja.

DFID. 1998. Transferring road maintenance into the private sector: preliminary literature review and proposed study area for the project. Department for International Development, London. $12 \mathrm{p}$.

DFT. 2009. Design manual for roads and bridges. environmental design and management: landscape management, Vol. 11, Sec. 3. London: Department for Transport.

Dlesk, J. R.; Bell, C. L. 2006. Outsourcing versus in-house highway maintenance: cost comparison and decision factors. SCDOT Research Project 653. Department of Civil Engineering, Clemson University.

Federal Roads Maintenance Agency. 2007. Annual report [online], [cited 29 March 2011]. Available from Internet: http://www.ferma.gov.ng/sites/all/themes/theme551/ download/2007ar.pdf

Federal Roads Maintenance Agency. 2009. Annual report [online], [cited 29 March 2011]. Available from Internet: http://www.ferma.gov.ng/sites/all/themes/theme551/ download/2009ar.pdf

FHWA. 2004a. Collaborative leadership: success stories in transportation mega projects. A "Lessons Learned" 
Approach to Collaborative Leadership in Mega Project Management. US Federal Highway Agency, Washington DC.

FHWA. 2004b. FAQs about highway and the economy. US Federal Highway Agency, Washington DC.

Gahm, G. 2008. Blir bevarandet av vägkapitalet nedprioriterat? [Is the preservation of road assessment low prioritized?]. ViaNordica, Helsinki (in Swedish).

Halcrow. 2011. National roads maintenance review: phase 2 report. Glasgow: Halcrow Group Limited. 35 p.

Hicks, G.; Seeds, B. S.; Peshkin, D. G. 2000. Selecting a preventive maintenance treatment for flexible pavements. Foundation for Pavement Preservation, Washington, DC. 87 p.

Highway Agency. 2009. M25 DBFO (Design, Build, Finance and Operate) contract. London: Highway Agency.

HM Treasury. 2012. Types of maintenance on the trunk roads [online], [cited 25 July 2012]. Available from Internet: http://www.hm-treasury.gov.uk/d/ias_16_guidance_ types_of_maintenance_on_the_trunk_roads.pdf

Infrastructure $\bar{C}$ Consortium for Africa (ICA) $)$. 2010. European Union cooperates with DRC in road renewal project [online], [cited 01 August 2012]. Available from Internet:

http://www.icafrica.org/en/news/infrastructure-news/article/ european-union-cooperates-with-drc-in-road-renewal-project-1193/

International Labour Organization (ILO). 2012. Road maintenance definitions and practice [online], [cited 01 July 2012]. Available from Internet:

http://www.ilo.org/public/english/employment/recon/eiip/ asist/asist-ap/download/rmdandp.pdf

Jahren, C. K.; Bergeson, K. L.; Al-Hammadi, A.; Celik, S.; Lau, G. 1999. Thin maintenance surfaces: phase one report. Center for Transportation Research and Education, Iowa State University. $57 \mathrm{p}$.

Kaplan, R. S.; Norton, D. P. 2005. Creating value from organizational alignment, Harvard Business Review 7(6): 1-16.

Karim, H. 2010. Evaluation of attempts for efficient road maintenance - knowledge compilation, Baltic Journal of Road and Bridge Engineering 5(4): 229-239. http://dx.doi.org/10.3846/bjrbe.2010.31

Karim, H. 2011. Road design for future maintenance - lifecycle cost analyses for road barriers: PhD Thesis. Royal Institute of Technology, Stockholm, Sweden. 79 p.

Kumaraswamy, M. M.; Zhang, X. Q. 2001. Governmental role in BOT-led infrastructure development, International Journal of Project Management 19(4): 195-205. http://dx.doi.org/10.1016/S0263-7863(99)00069-1

Lancelot, E. 2010. Performance based contracts in the road sector: towards improved efficiency in the management of maintenance and rehabilitation. Brazil's Experience Transportation Papers, TP-31. The World Bank Group, Washington DC.

New Hampshire DOT. 2011. NHDOT balanced scorecard 2011: measuring, managing and communicating NHDOT's transportation performance. New Hampshire Department of Transportation. $84 \mathrm{p}$.

Noble, J. W. B. 2004. Long term road maintenance contracts in Western Australia - lessons learnt, in Proc. of the $6^{\text {th }}$ International Conference on Managing Pavements (ICMP2004), 19-24 October 2004, Brisbane, Australia. 10 p.

North Wales Trunk Road Agency. 2013. Capital maintenance: what is a capital scheme? [online], [cited 23 January 2013]. Available from Internet:

http://www.northwales-tra.gov.uk/index.php?id=317\&L=0

Ondo State Government. 2012. Lagos-ibadan expressway: FG outlines concession terms breached by bi-courtney [online], [cited 03 January 2012]. Available from Internet: http://www.ondostate.gov.ng/press_release/Lagos1.pdf

Orugbo, E. E.; Alkali, B. M.; DeSilva, Ä.; Harrison, D. 2012. Reliability analysis of trunk road network maintenance: a study of category1 defects, in Proc. of the $27^{\text {th }}$ National
Conference on Manufacturing Research (NCMR-2012), 11-13 September 2012, Birmingham, UK, 115-120.

Österberg, R. 2003. Contracting out Public Services: an evaluation of the public consequences of opening up routine road maintenance to competition: Doctoral Thesis. The Swedish Royal Institute of Technology, Stockholm, Sweden.

Osime, O. C.; Ehikhamenor, E.; Oludiran, O.; Iribhogbe, P. E.; Ighedosa, S. E.; Elusoji, S. O. 2006. Road traffic accident trends in Nigeria, International Journal of Injury Control and Safety Promotion 13(4): 251-253.

http://dx.doi.org/10.1080/17457300600622282

Ozbek, M. E. 2004. Development of performance warranties for performance based road maintenance contracts: Master's Thesis. Virginia Polytechnic Institute and State University, Virginia. $354 \mathrm{p}$.

Ozbek, M. E.; de la Garza, J. M.; Triantis, K. 2010. Data and modeling issues faced during the efficiency measurement of road maintenance using data envelopment analysis, Journal of Infrastructure Systems 16(1): 21-31.

http://dx.doi.org/10.1061/(ASCE)1076-0342(2010)16:1(31)

PAGplus. 2009. The performance audit group's annual report 2009: an independent public report on Scotland's trunk road maintenance. Glasgow: PAGplus Halcrow Group Ltd.

PAGplus. 2010. The performance audit group's annual report 2010: an independent public report on Scotland's trunk road maintenance. Glasgow: PAGplus Halcrow Group Ltd.

Palmer, K. 2000. Contract issues and financing in PPP/PFI: do we need the $F$ in $D B F O$ projects? London: Cambridge Economic Policy Associates Ltd. 25 p.

Piñero, C. J.; de la Garza, J. M. 2003. Issues related to the assessment of performance-based road maintenance contracts, in Proc. of the $4^{\text {th }}$ Joint International Symposium on Information Technology in Civil Engineering (ITCE-2003), 15-16 November 2003, Nashville, Tennessee, 1-8.

Piñero, J. C. 2003. A framework for monitoring performancebased road maintenance: PhD Thesis. Virginia Polytechnic Institute and State University, Blacksburg, VA. 367 p.

Porter, T. 2006. International trends in procurement models for highway maintenance, in N. Stankevich, N. Qureshi, C. Queiroz (Eds). Resource guide: performance-based contracting for preservation and improvement of road assets. The World Bank, Washington DC.

Porter, T. 2001. International trends in procurement models for highway maintenance, in TRB Meeting, 7-11 January 2001, Opus International Consultants, Washington DC. 8 p.

Road Traffic Technology. 2012. Nigeria to start Lagos-Ibadan Expressway reconstruction [online], [cited 21 January 2012]. Available from Internet:

http://www.roadtraffic-technology.com/news/newsnigeriastarts-lagos-ibadan-expressway-reconstruction/

Schliessler, A.; Bull, A. 2004. Road network management, roads: a new approach for road network management and conservation. $2^{\text {nd }}$ ed. United Nations Economic Commission for Latin America and the Caribbean, Germany.

Segal, G. F.; Moore, A. T.; McCarthy, S. 2003. Contracting for road and highway maintenance [online], [cited 07 July 2011]. Available from Internet:

http://www.esd.worldbank.org/pbc_resource_guide/Docslatest $\% 20$ edition/cases-and-pdfs/htg21.pdf

Shaoul, J.; Stafford, A.; Stapleton, P. 2007. Highway robbery? A financial analysis of design, build, finance and operate (DBFO) in UK roads, Transport Reviews: a Transnational Transdisciplinary Journal 16(3): 257-274.

Silva, M.; Liautaud, G. 2011. Performance-based road rehabilitation and maintenance contracts (CREMA) in Argentina: a review of fifteen years of experience (1996-2010). Transport Papers, TP-36. 
Stankevich, N.; Qureshi, N.; Queiroz, C. 2005. Performancebased contracting for preservation and improvement of road assets. Transport Note No. TN-27. The World Bank.

Stenbeck, T. 2004. Incentives to innovations in road and rail maintenance: Licentiate Thesis. Royal institute of Technology, Sweden, Stockholm. 146 p.

Stenbeck, T. 2007. Promoting innovation in transportation infrastructure maintenance: $\mathrm{PhD}$ Thesis. Royal Institute of Technology, Sweden, Stockholm. 49 p.

The Secretariat for the Committee on Infrastructure. 2006. Financing of the national highway development programme. The Secretariat for the Committee on Infrastructure, New Delhi.

The Secretariat for the Committee on Infrastructure. 2009. Public private partnership in OMT of highways: overview of the framework [online], [cited 12 June 2011]. Available from Internet: http://www.infrastructure.gov.in/pdf/MCA OMT Overview final.pdf

Transport Scotland. 2010. Scottish trunk road maintenance and performance audit. Transport Scotland, Glasgow, UK.

Tomanelli, S. N. 2003. Evaluating and managing performancebased contracts, in Federal Publications Seminar LLC., Falls Church, Virginia, USA.

Transport Research Board. 2009. Performance-based contracting for maintenance: a synthesis of highway practice. NCHRP Program Synthesis 389, Washington DC.

UK Roads Liaison Group. 2005. Well-maintained highways code of practice for highway maintenance management. UK Roads Liaison Group, London.

Wallace, E. 2012. Pursuing change: the national road maintenance review in Scotland. Association for Public Service Excellence (APSE), Hamilton, UK.

Washington State Department of Transport. 2004. Review of highway maintenance outsourcing [online], [cited 18 May 2011]. Available from Internet:

http://www.wsdot.wa.gov/NR/rdonlyres/6100788C-F371-4654-

90DD-89F8FD0FFF1B/0/HwyMaintenanceOutsource.pdf
Wei, C.; Tighe, S. 2003. Development of preventive maintenance decision trees based on cost-effectiveness analysis: an Ontario case study, Journal of the Transportation Research Board 1866(2): 8-19.

World Bank. 2008: A user guide to road management tools. World Bank, Washington DC. 171 p.

World Bank. 2011. PPP in infrastructure resource centre. management and operations and maintenance $(O \& M)$ Contracts. World Bank, Washington DC.

Zietlow, G. 2004. Implementing performance-based road management and maintenance contracts in developing countries: an instrument of German technical cooperation. German Development Cooperation, Eschborn, Germany.

Zietlow, G. 2006. Performance-based contracting for preservation and improvement of roads assets: introduction and overview [online], [cited 13 March 2012]. Available from Internet: http://www-esd.worldbank.org/pbc_resource_guide/TrainingMaterial.htm

Zietlow, G. 2011. Cutting costs and improving quality through performance-based road management and maintenance contracts: the Latin American and OECD experiences, Presented at the Senior Road Executives Course, 24-29 April 2005, Road Sector Reform, Birmingham, UK.

Zhou, G. 2011. Co-location decision tree for enhancing decision-making of pavement maintenance and rehabilitation: $\mathrm{PhD}$ Thesis. Virginia Polytechnic Institute and State University, Virginia. 164 p.

\section{Appendix 1}

\section{Questions for Decision Tree}

${ }^{1}$ Is it project level road maintenance works that is to be procured? ( $\mathrm{Y}=$ Yes; $\left.\mathrm{N}=\mathrm{No}\right)$

${ }^{2}$ Is the proposed road maintenance works to be procured with an existing road maintenance outsourcing variant?

${ }^{3}$ Are the capabilities and limitations of existing road maintenance outsourcing variants evident to you?

${ }^{4}$ Have you examined ways you can overcome and take advantage of these opportunities and minimize threats by exploiting threats and offsetting identified weakness?

${ }^{5}$ Do the strengths and opportunities of existing road maintenance outsourcing variants align with your core organizational objectives for outsourcing road maintenance?

${ }^{6}$ Is cost reduction the core objective?

${ }^{7}$ Is access to expertise the core objective?

${ }^{8}$ Is risk reduction the core objective?

${ }^{9}$ Is access to finance the core objective?

${ }^{10}$ Is efficiency improvement the core objective?

${ }^{11}$ Is service improvement the core objective?

${ }^{12}$ Is life cycle cost reduction the core objective?

${ }^{13}$ Does your organization have SMART metrics to measure these core objectives of outsourcing? 


\section{Appendix 2}

\section{Balance Score Card Analysis}

\begin{tabular}{|c|c|c|c|}
\hline \multicolumn{2}{|c|}{ Expertise Perspective } & \multicolumn{2}{|c|}{ Service Perspective } \\
\hline Objectives & Measures & Objective & Measures \\
\hline $\begin{array}{l}\text { Skills level } \\
\text { upgrade }\end{array}$ & $\begin{array}{l}\text { Increase training } \\
\text { days per } \\
\text { employee } \\
\text { by } 15 \%\end{array}$ & $\begin{array}{l}\text { Improve customer } \\
\text { experience on } \\
\text { network }\end{array}$ & $\begin{array}{l}\text { Reduce } \\
\text { complaints by } 30 \% \text { and } \\
\text { increase response time } \\
\text { by } 20 \%\end{array}$ \\
\hline Use of technology & $\begin{array}{l}\text { Acquire and } \\
\text { use CMMS }\end{array}$ & & \\
\hline \multicolumn{2}{|c|}{ Investment Perspective } & \multicolumn{2}{|c|}{ Risk Perspective } \\
\hline Objectives & Measures & Objective & Measures \\
\hline $\begin{array}{l}\text { To invest } \\
£ 500 \text { million } \\
\text { on the network }\end{array}$ & $\begin{array}{l}\text { Reduce road } \\
\text { maintenance } \\
\text { backlog by } 50 \%\end{array}$ & $\begin{array}{l}\text { Reduce risk and } \\
\text { claims on networks }\end{array}$ & $\begin{array}{l}\text { Reduce category } 1 \\
\text { defect incidence by } \\
30 \%\end{array}$ \\
\hline
\end{tabular}

\section{CMMS - Computer Maintenance Management System}

Ena E. ORUGBO. He has just completed his thesis while studying for a $\mathrm{PhD}$ at the School of Engineering and Built Environment at Glasgow Caledonian University, UK. He is a member of the Institution of Mechanical Engineers UK and Association of Maintenance Professionals USA. His research interest includes maintenance optimization of complex physical infrastructures, particularly improved trunk road network maintenance decision making.

Babakalli M. ALKALI. He is a senior lecturer in maintenance and reliability management and the programme leader for MSc Maintenance Management at the School of Engineering and Built Environment at Glasgow Caledonian University, UK. He is a Fellow of the Higher Education Academy in the UK and member of the operational research society in the UK. His research interests are in reliability modelling and management, maintenance optimisation, probability modelling, risk analysis, energy asset management, transport research, statistical process control and stochastic modelling.

Anjali DESILVA. She is a Reader at the School of Engineering and Built Environment, Glasgow Caledonian University, UK. She currently teaches the Non-Destructive Testing Methodology module within the MSc Maintenance Management suite. Her research interests is primarily unconventional machining processes (manufacturing area) and includes electrochemical machining; electro discharge machining; laser machining; hybrid processes; micro machining; rapid tooling and manufacturing; high speed cutting and forming.

David K. HARRISON. He is a Professor in the School of Engineering and Built Environment at Glasgow Caledonian University, UK. He is currently the Chair of the Higher Degrees Committee of Glasgow Caledonian University. He is also the Subject Group Leader for Mechanical and Manufacturing. His research interests are primarily concerned with improving overall manufacturing competitiveness in companies via Optimised Design, CADCAM and advances towards CIM. 